\title{
Hubungan Interaktif Antara Harga Logam Mulia dan Jakarta Islamic Stock Index
}

\author{
Roni Padliansyah ${ }^{1}$, Ahmad Juliana ${ }^{2}$, La Ode Hasiara ${ }^{3}$ \\ 1,2 Program Studi Manajemen, Universitas Borneo Tarakan \\ e-mail: ${ }^{1}$ ronipadliansyah@gmail.com, ${ }^{2}$ ahmadjuliana75@gmail.com \\ ${ }^{3}$ Jurusan Akuntansi, Politeknik Negeri Samarinda \\ e-mail: hasiara@polnes.ac.id

\begin{tabular}{ccc}
\hline Diterima & Direvisi & Disetujui \\
$01-01-2020$ & $23-01-2020$ & $27-01-2020$ \\
\hline
\end{tabular}

\begin{abstract}
Abstrak - Penelitian ini bertujuan untuk mengetahui korelasi jangka panjang dan jangka pendek antara harga logam mulia yang terdiri dari emas, perak, platinum, paladium, dan Jakarta Islamic Stock Index (JKII). Data yang digunakan adalah data harian periode tanggal 2/2/2014 sampai dengan tanggal 29/4/2019. Data JKII di peroleh dari YahooFinance, dan untuk harga logam mulia dari Taiwan Economic Journal (TEJ) database. Uji Ko-integrasi Johanson (Johanson co-integration test), uji kausalitas Granger (Granger causality test), respos impuls (Impulse response analysis), dan variance decomposition method digunakan untuk mengklarifikasi korelasi jangka panjang dan jangka pendek antara kelima variable. Berdasarkan hasil uji akar unit (unit root test) yang dilakukan memperlihatkan bahwa seluruh variable stasioner pada diferensial orde pertama. Uji ko-integrasi Johansen menunjukkan tidak satupun variable yang berkointegrasi dalam periode jangka panjang. Uji kausalitas Granger menunjukan bahwa emas dan paladium menunjukan hubungan kausalitas dua arah dengan JKII, sedangkan untuk perak dan platinum hanya menunjukan hubungan kausalitas satu arah yang berarti setiap perubahan JKII akan berpengaruh terhadap harga perak dan platinum. Hasil analisis impulse respons, dan variance decomposition method menunjukkan effek dari setiap variable terhadap variable lainnya hanya terdapat pada periode 1 sampai dengan 5 dan menghilang pada periode selanjutnya atau hanya hubungan jangka pendek. Hasil penelitian ini memberikan implikasi praktis bagi akademisi, praktisi yang bertindak sebagai manajer portofolio, dan pembuat kebijakan. Implikasi ini terkait dengan manajemen risiko portofolio, manfaat diversifikasi, dan untuk mengusulkan alat investasi baru, yaitu pasar saham syariah di Indonesia.
\end{abstract}

Kata Kunci: Logam Mulia, Jakarta Islamic Stock Index, Time-Series Analysis

\begin{abstract}
The purpose of this study is to determine the long-term and short-term correlation between the prices of precious metals consisting of gold, silver, platinum, palladium, and the Jakarta Islamic Stock Index (JKII). The data used is daily data for the period 2/2/2014 to 29/4/2019. JKII data was obtained from Yahoo Finance and for the price of precious metals from the Taiwan Economic Journal (TEJ) database. Johansen cointegration test, Granger causality test, Impulse response analysis, and the Variance decomposition method are used to clarify long-term and short-term correlations between the five variables. Firstly, the unit root test result shows that all variables stationary in the first-order differential. Johansen's co-integration test shows that none of the variables are cointegrated in the long-term period. The Granger causality test shows that gold and palladium show a two-way causality relationship with the Islamic stock index, whereas for silver and platinum only shows a one-way causality relationship, which means that any changes in the Islamic stock index will affect the price of silver and platinum. The results of the impulse response analysis, and the Variance decomposition method show the effect of each variable on other variables found only in periods 1 to 5 and disappearing in the next period or only short-term relationships. These results provide practical implications for academics, practitioners who act as portfolio managers, and policymakers. This implication is related to portfolio risk management, diversification benefits, and to propose a new investment tool, namely the Islamic stock market in Indonesia.
\end{abstract}

Keywords: Precious metals, Jakarta Islamic Stock Index, Time-Series Analysis

\section{PENDAHULUAN}

Volatilitas tinggi di pasar keuangan membutuhkan diversifikasi portofolio yang efektif untuk meminimalkan risiko (Hamao, Masulis, \& $\mathrm{Ng}$, 1990). Sehingga, memahami hubungan jangka panjang antara aset keuangan yang dimasukkan dalam portofolio adalah penting untuk meminimalkan risiko 
keseluruhan portofolio. Investor umumnya mencari aset dengan average returns yang paling menguntungkan serta memiliki hubungan negatif dengan saham dan portofolio obligasi (Arouri, Lahiani, \& Nguyen, 2015; Choudhry, Hassan, \& Shabi, 2015). Logam mulia sebagai aset yang memiliki korelasi rendah dengan pasar saham, menjadikannya menarik bagi investor yang berusaha menghindari risiko (Baur \& Lucey, 2010; Chkili, 2017; Hood \& Malik, 2013). Logam mulia (seperti emas, perak, platinum dan paladium) adalah alat diversifikasi portofolio yang penting untuk mengatasi ketidakpastian di pasar keuangan karena berbagai alasan (Sensoy, 2013). Dengan kata lain, logam berharga dapat menjadi alat diversifikasi yang efektif dalam portofolio yang dibuat sebagai alternative alat investasi, selain saham, obligasi, derivatives dan mata uang asing, untuk meminimalkan risiko pada tingkat pendapatan yang ditargetkan oleh investor dalam periode volatilitas yang signifikan.

Krisis keuangan global 2008 mengindikasikan perlunya sebuah produk keuangan yang lebih baru serta pencarian diversifikasi portofolio yang efektif di pasar keuangan (Abdul Karim, Akila Mohd. Kassim, \& Affendy Arip, 2010). Pada saat itu, sistem keuangan Islam dan produk-produknya dianggap sebagai cara untuk keluar dari krisis dan mulai banyak disukai oleh investor. Mengingat sifat praktik keuangan Islam yang meluas, produk-produk keuangan baru mulai dikembangkan termasuk Sukuk (sertifikat obligasi / kontrak syariah), Dow Jones Islamic Market (DJIM) dan Global Islamic Index Series. Seiring dengan munculnya produk-produk keuangan baru ini sebagai alternatif untuk alat investasi tradisional, pasar saham syariah, yang mulai muncul setelah tahun 1990-an, juga muncul di pasar keuangan sebagai pilihan yang baik bagi semua investor yang mencari perlindungan dari inflasi (Gheeraert \& Weill, 2015; Haseeb, 2018). Pada saat yang sama, fakta bahwa aset syariah memberikan manfaat diversifikasi tinggi meningkatkan minat investasi syariah pada awal krisis keuangan terbaru (Mensi, Hammoudeh, \& Kang, 2015).

Indonesia sebagai negara dengan penduduk muslim terbesar di dunia merupakan pasar potensial saham syariah. Perkembangan dan kepouleran saham syariah dari tahun ke tahun di Indonesia mengalami peningkatan seperti yang diperlihatkan oleh Jakarta Islamic Index (JKII) (Gambar 1) sebagai salah satu alat ukur kinerja pasar modal syariah di Indonesia (Suciningtias \& Khoiroh, 2015). Oleh sebab itu studi mengenai pasar saham syariah menjadi penting untuk menjawab pertanyaan bagaimana investor di Indonesia akan mengadopsi dan menerapkan syariat Islam dalam mendiversifikasikan investasi mereka di pasar saham syariah.

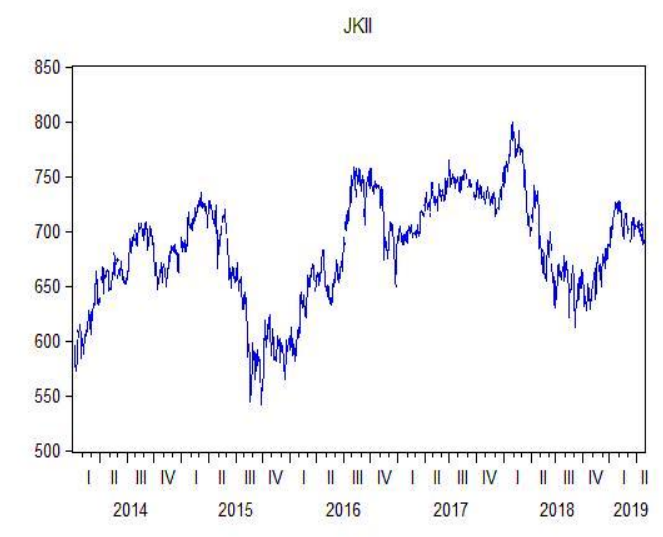

Gambar 1 Pergerakan Jakarta Islamic Index 2/2/2014 s/d 29/4/2019

Mayoritas studi mengenai logam muliah umumnya hanya bertujuan untuk membuktikan bahwa emas adalah safe heaven dan sebagai alat lindung nilai atau hedging tool (Baur \& Lucey, 2010; Chkili, 2017; Robiyanto, 2018). Misalnya pada penelitian Baur and Lucey (2010) hanya fokus mempelajari hubungan yang konstan dalam suatu rentang waktu antara saham di AS, Inggris, dan Jerman serta return obligasi dan return emas. Menyelidiki emas sebagai lindung nilai (hedging) dan safe heaven. Ini tentunya berbeda dengan penelitian yang dilakukan penulis saat ini karena dalam penelitian ini melibatkan unsur syariat Islam yang menjadikan logam mulia sebagai alternative investasi pada pasar saham syariah. Penelitian itu juga menemukan bahwa emas adalah alat lindung nilai terhadap saham rata-rata dan tempat yang aman (safe heaven) dalam kondisi pasar saham dengan volatilias ekstrim.

Penelitian terbaru yang dilakukan Robiyanto (2018) menganalisa fungsi emas sebagai safe heaven dan hedging tool untuk pasar saham syariah di Indonesia. Hanya saja penelitian ini hanya fokus pada satu jenis logam mulia yaitu emas, sedangkan dalam penelitian ini memasukkan jenis logam mulia lainnya seperti perak, platinum, dan paladium. Dari segi data serta metode, penelian ini sangat berbeda dengan yang sudah dilakukan Robiyanto (2018). Penelitian ini menggunakan data harian yang dapat lebih akurat menangkap volatilitas pasar keuangan yang memiliki karakteristik fluktuasi harga yang tinggi (Andersen, Bollerslev, Diebold, \& Labys, 2003). Metode yang digunakan dalam penelitian ini adalah time-series analysis yang merupakan metode paling umum digunakan untuk memprediksi interaksi antar variable dalam bidang keuangan, sedangkan Robiyanto (2018) menggunakan OLS and QREG.

Kebanyakan penelitian tentang logam berharga berfokus pada studi tentang apakah logam berharga adalah alat lindung nilai dan diversifikasi yang efektif, serta penelitian tentang perbandingan pasar saham konvensional dan pasar saham syariah (Ajmi, Hammoudeh, Nguyen, \& Sarafrazi, 2014; Al- 
Khazali, Lean, \& Samet, 2014; Ashraf \& Mohammad, 2014). Bertolak belakang dengan pelitian yang mengkaji tentang peranan logam mulia dalam pasar keuangan syariah yang amat terbatas.

Arouri et al. (2015)menggunakan kerangka kerja VAR-GARCH dari Ling and McAleer (2003) untuk mengeksplorasi return dan spillover volatilitas antara harga emas dunia dan pasar saham di China selama periode 22/3/2004 sampai 31/3/ 2011. Hasil penelitian mereka menunjukkan bukti signifikan return dan efek lintas volatilitas antara harga emas dan harga saham di Cina, serta menunjukkan keunggulan model VAR-GARCH dibandingkan spesifikasi GARCH multivarian lainnya. Secara khusus, return emas pada masa lalu memainkan peran penting dalam menjelaskan dinamika conditional return dan volatilitas pasar saham Cina dan karenanya harus diperhitungkan ketika memperkirakan return saham di masa depan.

Selanjutnya, Nagayev, Disli, Inghelbrecht, and $\mathrm{Ng}$ (2016) menyelidiki apakah komoditas menawarkan potensi keuntungan diversifikasi bagi investor indeks saham syariah mengingat kemungkinan finansialisasi pasar komoditas. Menggunakan MGARCH-DCC dan Wavelet Coherence analisis, temuan mereka mengungkapkan bahwa korelasi antara pasar komoditas dan Dow Jones Islamic Market World Index sangat fluktuatif selama periode Januari 1999 s/d April 2015. Temuan ini memiliki implikasi bagi investor yang sangat heterogen dalam mentolerir risiko dan memili preferensi waktu, serta bagi para pembuat kebijakan yang bertanggungjawab terhadap stabilitas pasar.

Chkili (2017) menggunakan pendekatan switching Markov untuk menyelidiki peran emas sebagai lindung nilai (hedge) atau safe haven untuk risiko pasar saham syariah. Hasil empiris mengungkapkan di satu sisi, kehadiran dua rezim yang berbeda untuk semua pasar yang dipertimbangkan yaitu rezim dengan volatilitas rendah dan rezim dengan volatilitas tinggi. Lebih tepatnya, rezim volatilitas tinggi bertepatan dengan peristiwa utama ekonomi dan politik yang terjadi selama periode yang diteliti. Di sisi lain, studi ini menunjukkan bahwa emas adalah alat lindung nilai yang lemah dan tempat berlindung (safe haven) yang kuat terhadap pergerakan pasar saham Islam yang ekstrem. Hasil ini memiliki implikasi signifikan untuk diversifikasi portofolio dan pilihan strategi lindung nilai (hedge).

Majid and Shabri (2018) mengeksplorasi dominasi pasar saham Islam dunia di Jepang, Inggris, dan AS atas pasar saham syariah di Indonesia. Tes Kausalitas Granger (Granger causalities) berdasarkan kerangka Vector Error Correction Model (VECM) diadopsi untuk mengidentifikasi secara empiris gerakan bersama (co-movement) di antara pasar saham syariah. Studi ini menemukan bahwa pasar saham syariah di Indonesia, Inggris, Jepang, dan AS sedang bergerak menuju tingkat integrasi yang lebih besar. Pasar saham syariah Jepang secara dominan ikut mengerakkan saham syariah Indonesia, sebagaimana dengan pasar saham syariah Inggris dan AS yang memiliki hubungan bivariat dan multivarian. Ini lebih lanjut menyiratkan bahwa setiap perkembangan di pasar keuangan syariah Jepang harus lebih diperhatikan oleh otoritas Indonesia dalam merancang kebijakan untuk menstabilkan dan mempromosikan pasar saham syariahnya.

Studi terbaru dari Tuna (2019) bertujuan untuk menganalisis adanya hubungan jangka panjang antara harga logam mulia, seperti untuk emas, perak, platinum dan paladium, dalam 32 pasar saham syariah berbagai negara yang terdiri dari 21 negara maju dan 11 negara berkembang menggunakan analisis Pedroni panel cointegration analysis dan full modified ordinary least square (FMOLS) method. Semua analisis dalam penelitian ini dilakukan dengan menggunakan data bulanan dari 2002 hingga 2015. Berdasarkan Pedroni panel cointegration analysis yang diterapkan dalam penelitian ini, semua variable yaitu logam berharga (emas, perak, platinum, dan paladium) adalah alat diversifikasi portofolio yang efektif untuk Pasar saham syariah negara berkembang dalam periode yang dianalisis. Namun, di negara berkembang, hanyai emas dan paladium yang merupakan alat diversifikasi portofolio yang efektif, sedangkan untuk perak dan platinum tidak.

Dari seluruh penelitian di atas dapat kita lihat bawa terdapat berbagai macam metode untuk menguji hubungan logam mulia dengan pasar saham syariah, oleh sebab itu untuk mengembangkan dan membuktikan hubungan interaksi antara logam mulia dan pasar saham syariah masih diperlukan studi dengan metode dan pendekatan lainnya. Serta, diperlukan penelitian lanjutan yang berfokus pada pasar saham syariah di Indonesia yang mana masih sangat terbatas studi pasar saham syariah yang dapat memberikan informasi untuk para investor maupun pembuat kebijakan.

Penelitian ini dilakukan untuk memperkaya studi tentang hubungan harga logam mulia seperti emas, perak, platinum, paladium, dan pasar saham syariah khususnya pasar saham syariah di Indonesia. Untuk itu maka, uji ko-integrasi Johanson (Johanson co-integration test), uji kausalitas Granger (Granger causality test), respos impuls (Impulse response analysis), dan variance decomposition method digunakan untuk mengklarifikasi korelasi jangka panjang dan jangka pendek antara kelima variable.

\section{METODOLOGI PENELITIAN}

\section{Uji Akar Unit (Unit root test)}

Dalam model statistik deret waktu, variabel deret waktu harus diuji terlebih dahulu untuk menentukan apakah variabel adalah variabel stasioner. Pengujian ini dilakukan dengan menggunakan ADF (Dickey \& Fuller, 1979) unit root test. Hipotesis nolnya adalah $\mathrm{H}_{0}: \beta=0$. Jika $\mathrm{H}_{0}$ tidak dapat ditolak, rangkaian waktu $y t$ memiliki unit root dan tidak stasioner, maka kemudian dilakukan analisis 
diferensial sampai $\mathrm{H}_{0}$ ditolak dan data urutan variabel stabil.

Model estimasi adalah sebai berikut: tren waktu

Model 1: Model dengan intersep, tetapi tanpa

$$
\Delta Y_{t}=a_{0}+\beta Y \mathrm{t}-\mathrm{i}+\sum_{i=1}^{p} \rho i \Delta Y t-i+\varepsilon t
$$

Model 2: Model dengan intersep dan tren waktu

$\Delta Y_{t}=a_{0}+\beta Y \mathrm{t}-\mathrm{i}+\sum_{i=1}^{p} \rho i \Delta Y t-i+\gamma T+\varepsilon t$

di mana $\Delta$ menunjukkan diferensial orde pertama, $a_{0}$ mewakili intersep, $\gamma$ adalah tren waktu dalam model, $p$ menunjukkan jeda (lag) periode optimal yang membuat residu $s t$ menjadi white-noise. Pilihan optimal periode lag juga penting. Jika periode jeda (lag) terlalu lama, maka estimasi tidak akan efisien, dan residu $\varepsilon t$ tidak akan menjadi white-noise. Nilai-nilai kritis AIC dan SBC yang lebih kecil adalah metode yang lebih baik apabila digunakan untuk mengoptimalkan periode lag p: criterion):

$$
\text { Metode 1: AIC (Akaike information }
$$

$$
A I C=-2 \frac{\sigma}{M}+2 \times \frac{M}{N}
$$

Metode 2: SBC (Schwartz Bayesian criterion):

$$
S B C=-2 \frac{\sigma}{M}+2 \times \frac{N \log (M)}{M}
$$

$N$ adalah periode lag, $M$ menunjukkan jumlah sampel, dan $\sigma$ mewakili varians residual dari nilai kemungkinan maksimum.

\section{Uji ko-integrasi (The co-integration test)}

Tes ko-integrasi menentukan koneksi jangka panjang antar variabel. Engle and Granger (1987) mengusulkan teori Kointegrasi, yaitu bahwa variabel non-stasioner dapat menjadi variabel stasioner dengan kombinasi linear. Inilah yang dikatakan bahwa variabel-variabel ini memiliki hubungan ko-integrasi. Hubungan stabil jangka panjang dikatakan eksis di antara variabel-variabel ini dengan menguji jumlah kointegrasi kelompok vektor, berikut dua metode statistik yang digunakan:

Metode 1: Elemen diagonal dan uji jejak.

Tes jejak juga dikenal sebagai tes lintasan, dan tes statistiknya adalah sebagai berikut:

$$
\lambda \operatorname{trance}(r)=-T \sum_{i=r+1}^{n} \ln \left(1 \lambda^{\wedge} i\right)
$$

$\mathrm{H}_{0}$ : peringkat $(\Pi) \leq r$ maksimum $r$ grup vektor kointegrasi,

$\mathrm{H}_{1}$ : peringkat $(\Pi)>r$. Di mana $\Pi$ menunjukkan jumlah kelompok matriks-vektor independen, yaitu, jumlah nilai Eigen yang berbeda dari $0 ; T$ mewakili jumlah sampel; $r$ adalah jumlah kelompok vektor yang saling terintegrasi; $\lambda^{\wedge} \mathrm{i}$ menyatakan nilai estimasi dari nilai Eigen, dan $n$ mewakili jumlah nilai Eigen yang dihasilkan yang mematuhi distribusi chi-square $\left(\chi^{2}\right)$ yang sedang diperiksa.

Metode 2: Tes nilai Eigen maksimum:

Tes statistiknya adalah sebagai berikut:

$$
\lambda \operatorname{trance}(r, r+1)=-T \sum_{i=r+1}^{n} \ln \left(1 \lambda^{\wedge} i\right)
$$

$\mathrm{H}_{0}$ : peringkat $(\Pi)=r$ dan ada $r$ grup vektor kointegrasi,

$\mathrm{H}_{1}$ : peringkat $(\Pi)=r+1$. Di mana $\mathrm{T}$ menunjukkan jumlah sampel; $r$ mewakili jumlah kelompok vektor ko-integrasi dan $\lambda^{\wedge} \mathrm{i}$ adalah nilai estimasi nilai Eigen engan yang mematuhi distribusi chi-square $\left(\chi^{2}\right)$ yang sedang diperiksa.

\section{Vector auto-regression (VAR)}

Pendekatan ko-integrasi diusulkan oleh Engle and Granger (1987). Ko-integrasi menggambarkan kombinasi linear dari variabel tidak konstan, melibatkan data stasioner, dimana regresi memiliki implikasi ekonomi, sehingga hubungan ekuilibrium jangka panjang dapat diidentifikasi. Dalam studi ini mengadopsi uji ko-integrasi yang diusulkan oleh (Johansen, 1988). Model VAR adalah sebagai berikut:

$$
Y_{t}=\alpha+\sum_{i=1}^{p} \beta i Y_{t-i}+\varepsilon_{t}
$$

di mana $Y t$ menyatakan vektor $k x \quad l$ dari $k$ variabel endogen, $\alpha$ mewakili $k \times 1$ vektor konstanta (intersep), $\beta i$ adalah $\mathrm{k} \times \mathrm{p}$ matrix (untuk setiap $i=1, \ldots, \mathrm{p}$ ), $\varepsilon t$ dilambangkan sebagai kesalahan random independen dengan $E(\varepsilon t)=0$ dan $\operatorname{Var}(\varepsilon t)$ adalah konstan.

\section{Uji kausalitas Granger (Granger-causality test)}

Uji kausalitas Granger digunakan untuk menentukan kegunaan dari satu deret waktu dalam peramalan yang lain. Misalnya, ketika dua variabel, $\mathrm{x}$ dan $\mathrm{y}$ ada, jika $\mathrm{x}$ secara signifikan memprediksi $\mathrm{y}$, maka $\mathrm{x}$ dipertimbangkan sebagai penyebabnya, dan $\mathrm{y}$ dipengaruhi. Model regresinya adalah sebagai berikut:

$$
x_{t}=\alpha_{0}+\sum_{i=1}^{p} \omega_{i} x_{t-i}+\sum_{j=1}^{q} \varphi_{i} y_{t-j}+e_{t}
$$




$$
y_{t}=\beta_{0}+\sum_{i=1}^{s} \delta_{i} x_{t-i}+\sum_{j=1}^{t} \eta_{i} y_{t-j}+v_{t}
$$

Jika hasilnya menunjukkan adanya indikasi diterimanya nol hipotesis maka $\mathrm{H}_{1}$ ditolak. Dan dapat dikatakan bahwa variabel $\mathrm{x}$ memimpin variabel $\mathrm{y}$. Namun, jika kedua nol hipotesis $\mathrm{H}_{0}$ dan $\mathrm{H}_{1}$ ditolak, maka terdapat hubungan sebab akibat ada antara $\mathrm{x}$ dan y.

\section{Respon impuls dan dekomposisi varians (Impulse responses and variance decompositions)}

Fungsi respon impuls menunjukkan efek guncangan di jalur penyesuaian. Selain respon impuls, VAR menggunakan perkiraan dekomposisi varians galat untuk menganalisis perubahan antar variabel. Mengamati perubahan kesalahan prediksi untuk setiap variabel dan varians dari variabel lain mengungkapkan kekuatan relatif dari variabel eksogen dan fluktuasinya. Ramalan dekomposisi varians galat mengukur kontribusi setiap jenis guncangan untuk meramalkan kesalahan varians. Kedua perhitungan baik respon impuls maupun dekomposisi varians membantu menilai bagaimana guncangan terhadap variabel ekonomi bergema melalui suatu sistem.

\section{Respon impuls (Impulse responses)}

Model VAR dikonversi ke moving average vector (VMA) formulir. Oleh karena itu, setiap variabel dalam model dapat dianggap sebagai variabel endogen. Variabel endogen dengan demikian mencerminkan istilah kesalahan acak saat ini dan periode lag.

$$
\begin{gathered}
Y_{t}-\sum_{i=1}^{p} A_{i} Y_{t-i}=a+\varepsilon_{t} \\
Y_{t}=\left(I-A_{1} L-I-A_{1} L^{2}-\cdots-A^{P} L_{P}\right)^{-1} \alpha \\
+\left(I-A_{1} L-I-A_{1} L^{2}-\cdots-A^{P} L_{P}\right)^{-1} \varepsilon_{t}
\end{gathered}
$$

di mana $L$ adalah operasi lag, dan $I$ adalah matriks unit.

$$
Y_{t}=\alpha^{\prime}+\sum_{i=0}^{\infty} C_{i} \varepsilon_{t-i}
$$

Maka, $\mathrm{H}$ (matriks triangulasi yang lebih rendah; $\mathrm{HH}^{\prime}=$ I)

$$
Y_{t}=\alpha^{\prime}+\sum_{i=0}^{\infty} D_{i} W_{t-i}
$$

di mana $D i=C i H, W t-i=H^{\prime} \quad \varepsilon t-i$, Pers. (12), satusatunya urutan yang tidak memiliki hubungan dengan item kejut saat ini yang tidak terkait dan acak secara ortogonal. Ketika kejutan untuk variabel terjadi, melalui nilai Di, dampak dari variabel lain terungkap.

\section{Dekomposisi varians (Variance decompositions)}

Melanjutan Pers. (13), kita dapatkan

$$
\begin{gathered}
Y_{t}-E_{t-p}-Y_{t}=\sum_{i=0}^{\infty} C_{i} \varepsilon_{t-i} \\
-E_{t-n}\left(\sum_{i=0}^{\infty} C_{i} \varepsilon_{t-i}\right)
\end{gathered}
$$

dimana $E_{t-p} Y_{t}=E\left(Y_{t} \mid Y_{t-n-1}, Y_{t-n-2,} \ldots\right)$ digunakan untuk periode $t-p$ untuk memprediksi kesalahan yang dihasilkan $\mathrm{Y}_{\mathrm{t}}$. Matriks kovarians kesalahan prediksi yang sesuai adalah:

$$
\begin{aligned}
& E\left(Y_{t}-E^{\wedge}{ }_{t-p} Y_{t}\right)\left(Y_{t}-E^{\wedge}{ }_{t-p} \mid Y_{t}\right)^{\prime} E\left(Y_{t}-\right. \\
& \left.E_{t-p}^{\wedge} Y_{t}\right)\left(Y_{t}-E_{t-p}^{\wedge} \mid Y_{t}\right)^{\prime} \sum_{j=0}^{p-1} C_{i} \sum C_{i}^{\prime}
\end{aligned}
$$

Dimana

$$
\begin{gathered}
Q(i, p, j)=C_{0}^{2}(i, j)+C_{1}^{2}(i, j)+\cdots \\
+C_{t-p}^{2}(i, j), \mathrm{Q}(\mathrm{i}, \mathrm{p})= \\
\sum_{j=1}^{2} Q(i, p, j), Q(i, n, j) / Q(i, n)
\end{gathered}
$$

menunjukkan persentase dekomposisi varians antara variabel prediktif. Kekuatan relatif beragam variabel eksogen dapat ditentukan dan dijelaskan dengan merujuk ke variable lain.

\section{HASIL DAN PEMBAHASAN}

\section{Deskripsi Data}

Penelitian ini menggunakan data dari tanggal 2/2/2014 sampai dengan tanggal 29/4/2019. Berdasarkan Hamao et al. (1990), jika terdapat salah satu data dari kelima variable ditutup perdagangannya pada hari tertentu maka seluruh data variabel pada hari itu dapat dieliminasi. Hamao et al. (1990) berpendapat bahwa pemrosesan data seperti itu tidak akan mempengaruhi ketepatan hasil akhir dari sebuah studi empiris

Keseluruhan penjelasan dari kelima variable dapat dilihat pada tabel 1 di bawah ini. JKII adalah data Jakarta Islamic Index pada saat penutupan yang telah disesuaikan yang diperoleh dari database YahooFinance. GOLD, SILVER, PLATINUM, dan PALADIUM menunjukkan harga emas, perak, platinum, dan palladium di bursa logam London Metal Exchange yang merupakan pasar spot logam mulia paling tua dan penting di dunia. Data dari logam mulia tersebut diambil dari database Taiwan Economic Journal (TEJ). 
Tabel 3 Deskriptif Statistik

\begin{tabular}{lccccc}
\hline Variable & JKII & GOLD & SILVER & PLATINUM & PALADIUM \\
\hline Mean & 683.57 & 1243.22 & 16.76 & 1038.63 & 838.00 \\
Median & 688.05 & 1250.90 & 16.54 & 975.00 & 794.00 \\
Maximum & 798.77 & 1385.00 & 21.71 & 1511.00 & 1604.00 \\
Minimum & 542.00 & 1049.40 & 13.48 & 772.00 & 465.00 \\
Standard deviation & 49.28 & 68.25 & 1.78 & 196.25 & 220.86 \\
Skewness & -0.37 & -0.62 & 0.61 & 0.98 & 1.05 \\
Kurtosis & 2.59 & 2.89 & 2.81 & 2.88 & 4.28 \\
\hline
\end{tabular}

Sumber: Hasil olah data Eviews 7
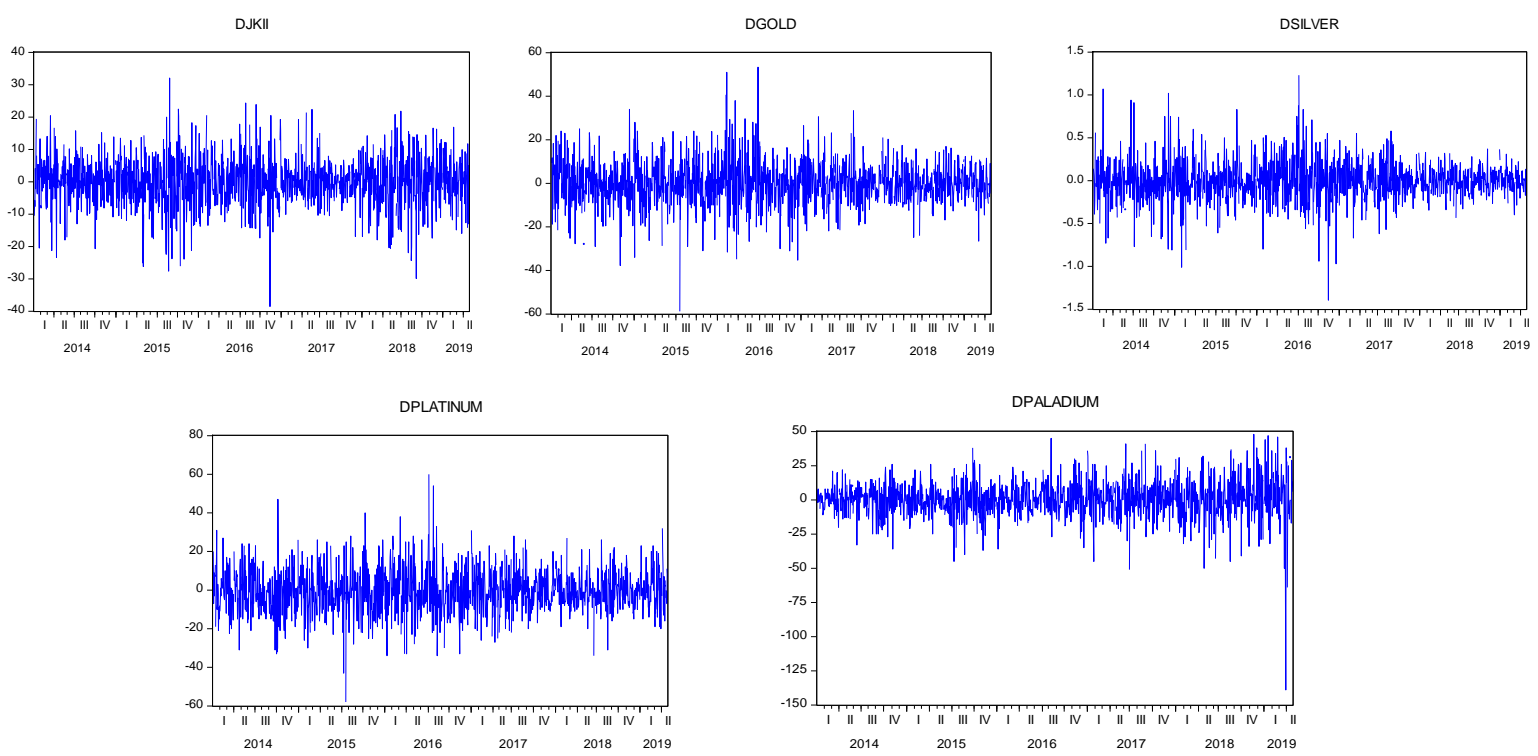

Sumber: Hasil olah data Eviews 7

Gambar 2 Grafik variabel dalam diferensial orde pertama

Tabel 1 Jenis dan Sumber Variabel

\begin{tabular}{lll}
\hline Kode Variable & Nama Variable & Data Base/Website \\
\hline JKII & Jakarta Islamic Index & YahooFinance \\
GOLD & London gold spot & TEJ* \\
SILVER & London silver spot & TEJ* \\
PLATINUM & London platinum spot & TEJ* \\
PALADIUM & London paladium spot & TEJ* \\
\hline
\end{tabular}

\section{Sumber: TEJ dan YahooFinance}

*TEJ adalah online subscribed database yang secara sepesial menyediakan data laporan keuangan dan data pasar saham.

Hasil uji akar unit (Unit root test) dan hasil uji kointegrasi Johansen (Johansen co-integration test)

Uji akar unit digunakan untuk mengkonfirmasi variabel JKII, GOLD, SILVER, PLATINUM, dan PALADIUM yang signifikan pada diferensial orde pertama, sehingga variabel stasioner dalam uji akar unit ADF. (Tabel 2 dan 3 dan Gambar 2).

Tabel 2 ADF untuk first order differential ${ }^{\mathrm{a}}$

\begin{tabular}{llll}
\hline Variable yang diuji & Intercept & $\begin{array}{l}\text { Trend dan } \\
\text { Intercept }\end{array}$ & None \\
\hline \multirow{2}{*}{$\Delta$ JKII } & $-17.0000^{* * *}$ & $-17.0147 * * *$ & $-16.9951^{* * *}$ \\
$\Delta$ GOLD & $-36.1416^{* * * *}$ & $-36.1280^{* * * *}$ & $-36.1552 * * *$
\end{tabular}

http://ejournal.bsi.ac.id/ejurnal/index.php/moneter

\begin{tabular}{|c|c|c|c|}
\hline$\triangle$ SILVER & $-35.7359 * * *$ & $-35.7244 * * *$ & $-35.7400 * * *$ \\
\hline$\triangle$ PLATINUM & $-12.4305 * * *$ & $-12.4636^{* * * *}$ & $-12.3763 * * *$ \\
\hline$\triangle$ PALADIUM & $-13.5086^{* * * *}$ & $-13.6158 * * *$ & $-13.4409 * * *$ \\
\hline
\end{tabular}

Sumber: Hasil olah data Eviews 7

$\Delta$ menandakan diferensial orde pertama.

${ }^{a}$ simbol $*, * *, * * *$, menunjukan signifikan level pada $10 \%, 5 \%, 1 \%$

Karena uji ko-integrasi Johansen didasarkan pada model autoregresif (VAR) sehingga pertama-tama panjang lag optimal perlu ditentukan untuk menghitung jumlah vektor terintegrasi. Default mundur adalah 12, lag optimal dipilih sesuai dengan kriteria AIC dan SBC, dan hasil lag optimal adalah 4. Uji ko-integrasi Johansen kemudian dilakukan untuk mengkonfirmasi keberadaan ko-integrasi antara variabel.

Tabel 4 menunjukkan bahwa Trace Statistics dan Max-Eigen Statistics tidak dapat menolak hipotesis nol, $r=0$ (none), $r \leq 1$ (at most 1 ), $r \leq 2$ (at most 2 ), $r \leq 3$ (at most 3 ), dan $r \leq 4$ (at most 4), pada tingkat signifikansi 5\%, sehingga hubungan kointegrasi dapat dikatakan tidak ada di antara semua variabel. Hasil ini juga mendukung konsep logam mulia dan pasar saham syariah tidak bergerak bersama atau dalam kata lain tidak berkorelasi dalam jangka panjang. Karena itu, logam mulia seperti emas, perak, platinum, dan paladium adalah alat diversifikasi 
portofolio yang efektif untuk pasar saham syariah.

\section{Hasil uji kausalitas Granger (Granger-causality test)}

Uji kausalitas granger menunjukan bahwa emas dan paladium menunjukan hubungan kausalitas dua

\section{Hasil respon impuls (Impulse responses)}

Sepuluh tolok ukur digunakan untuk memprediksi respons impuls, serta digunakan untuk menganalisis hubungan dinamis di antara kelima variable. Dari tabel 6-10 dan gambar 4 dapat kita lihat bahwa ke effek dari setiap variable terhadap

Tabel 4 Uji ko-integrasi Johansen (Johansen co-integration test)

\begin{tabular}{|c|c|c|c|c|}
\hline No. of CE(s) & Trace statistic & $5 \%$ Critical value & Max-eigen statistic & $5 \%$ Critical value \\
\hline \multicolumn{5}{|l|}{ None } \\
\hline \multicolumn{5}{|c|}{ No Intercept and no trend } \\
\hline $\mathrm{r}=0$ & 48.38138 & 60.06141 & 21.14372 & 30.43961 \\
\hline$r \leq 1$ & 27.23766 & 40.17493 & 12.99572 & 24.15921 \\
\hline$r \leq 2$ & 14.24195 & 24.27596 & 8.739618 & 17.7973 \\
\hline$r \leq 3$ & 5.502328 & 12.3209 & 5.479112 & 11.2248 \\
\hline$r \leq 4$ & 0.023215 & 0.023215 & 0.023215 & 4.129906 \\
\hline \multicolumn{5}{|c|}{ Intercept and no trend } \\
\hline $\mathrm{r}=0$ & 60.11895901 & 76.97276758 & 21.2500021 & 34.80587167 \\
\hline$r \leq 1$ & 38.8689569 & 54.07903636 & 17.5630579 & 28.58808006 \\
\hline $\mathrm{r} \leq 2$ & 21.30589901 & 35.19275463 & 9.413576536 & 22.29962298 \\
\hline$r \leq 3$ & 11.89232247 & 20.26183964 & 6.460871711 & 15.89209863 \\
\hline$r \leq 4$ & 5.43145075 & 5.43145075 & 5.43145075 & 9.16454591 \\
\hline \multicolumn{5}{|l|}{ Linear } \\
\hline \multicolumn{5}{|c|}{ Intercept and no trend } \\
\hline $\mathrm{r}=0$ & 52.17095054 & 69.81888745 & 20.48988522 & 33.87686662 \\
\hline $\mathrm{r} \leq 1$ & 31.68106531 & 47.85612716 & 17.51603546 & 27.58433779 \\
\hline$r \leq 2$ & 14.16502985 & 29.79707334 & 8.113646718 & 21.1316163 \\
\hline$r \leq 3$ & 6.051383137 & 15.49471288 & 6.030494075 & 14.26460015 \\
\hline$r \leq 4$ & 0.020889061 & 0.02088906 & 0.020889061 & 3.84146550 \\
\hline \multicolumn{5}{|c|}{ Intercept and trend } \\
\hline $\mathrm{r}=0$ & 69.62594969 & 88.80380063 & 27.18050321 & 38.33100834 \\
\hline $\mathrm{r} \leq 1$ & 42.44544648 & 63.87610362 & 17.54237804 & 32.11831694 \\
\hline $\mathrm{r} \leq 2$ & 24.90306844 & 42.91524703 & 12.50952502 & 25.82321075 \\
\hline$r \leq 3$ & 12.39354342 & 25.87210793 & 7.130573346 & 19.38704006 \\
\hline$r \leq 4$ & 5.262970069 & 12.51798289 & 5.262970069 & 12.51798289 \\
\hline
\end{tabular}

Sumber: Hasil olah data Eviews 7

arah dengan indeks saham syariah. Ini dapat diartikan bahwa setiap perubahan harga emas dan paladium akan mempengaruhi index saham syariah,

\begin{tabular}{lcc} 
Tabel 5 Hasil dari Granger causality test & & \\
\hline Null Hypothesis: & F-Statistic & P-value \\
\hline & & \\
$\Delta$ GOLD does not Granger Cause $\Delta$ JKII & 4.26597 & 0.01424 \\
AJKII does not Granger Cause $\Delta$ GOLD & 5.32423 & 0.00498 \\
$\Delta$ SILVER does not Granger Cause $\Delta$ JKII & 1.12009 & 0.32657 \\
AJKII does not Granger Cause $\Delta$ SILVER & 6.08695 & 0.00234 \\
APLATINUM does not Granger Cause $\Delta$ JKII & 1.27080 & 0.28096 \\
AJKII does not Granger Cause $\Delta$ PLATINUM & 3.89655 & 0.02055 \\
$\Delta$ PALADIUM does not Granger Cause $\Delta$ JKII & 2.34664 & 0.09610 \\
$\Delta$ JKII does not Granger Cause $\Delta$ PALADIUM & 2.43999 & 0.08757 \\
\hline Sumber: Hasil olah data Eviews 7 & &
\end{tabular}

begitu pula sebaliknya. Sedangkan untuk perak dan platinum hanya menunjukan hubungan kausalitas satu arah yang berarti setiap perubahan index saham syariah akan berpengaruh terhadap harga perak dan platinum (Tabel 5 dan Gambar 3). Walaupun hasil ini menunjukan adanya effek mempengaruhi tetapi uji ini hanya menjelaskan kegunaan dari suatu model yang menjelaskan variable mana yang membawa pengaruh terhadap variable lainnya tanpa bisa menjelaskan effek jangka panjang seperti yang terdapat pada uji kointegrasi Johansen atau uji respon impuls dan dekomposisi varians yang dapat menjelaskan hubungan jangka pendek pada setiap variable. variable lainnya hanya terdapat pada periode 1 sampai dengan 5 dan menghilang pada periode selanjutnya. Itu membuktikan bahwa interaksi variable logam mulia dan index saham syariah hanya terjadi dalam periode jangka pendek, dan dapat dikatakan bahwa setiap variable relative independent satu sama lainnya dalam periode jangka panjang. Hasil ini sesuai dengan hasil dari uji ko-integrasi Johansen yang dilakukan sebelumnya yang menyatakan bahwa variable logam mulia dan index saham syariah tidak berjalan bersamaan dalam periode jangka panjang.

\section{KESIMPULAN}

Penelitian ini menganalisa interaksi antara logam mulia yang terdiri dari emas, perak, platinum dan paladium dan index saham syariah di Indonesia. Data yang digunakan dalam penelitian ini adalah data harian dari bulan Februari 2014 sampai dengan April 2019. Uji ko-integrasi Johansen, uji kausalitas Granger, analisis impulse respons, dan Variance decomposition method digunakan untuk mengkonfirmasi hubungan jangka panjang dan jangka pendek antar variabel. Berdasarkan hasil studi empiris: seluruh variable stasioner pada diferensial orde pertama (Dickey \& Fuller, 1979). 
Tabel 6 Reaksi dampak index saham syariah terhadap gangguan dari variabel lain

\begin{tabular}{|c|c|c|c|c|c|}
\hline \multicolumn{6}{|c|}{ Response of $\Delta \mathrm{JKII}$ : } \\
\hline Period & $\Delta \mathrm{JKII}$ & $\Delta \mathrm{GOLD}$ & $\triangle$ SILVER & $\triangle$ PLATINUM & $\triangle$ PALADIUM \\
\hline 1 & 7.6057 & 0.0000 & 0.0000 & 0.0000 & 0.0000 \\
\hline 2 & -0.1389 & 0.5965 & 0.0349 & 0.1197 & 0.2367 \\
\hline 3 & -0.5635 & -0.1350 & 0.3059 & 0.0183 & 0.1986 \\
\hline 4 & 0.0757 & 0.0428 & -0.0771 & -0.0233 & -0.0340 \\
\hline 5 & 0.0415 & 0.0277 & -0.0247 & 0.0000 & -0.0259 \\
\hline 6 & -0.0079 & -0.0170 & 0.0139 & 0.0033 & 0.0045 \\
\hline 7 & -0.0021 & 0.0003 & -0.0004 & -0.0006 & 0.0021 \\
\hline 8 & 0.0003 & 0.0020 & -0.0010 & -0.0002 & -0.0004 \\
\hline 9 & 0.0002 & -0.0004 & 0.0002 & 0.0001 & -0.0001 \\
\hline 10 & 0.0000 & -0.0001 & 0.0000 & 0.0000 & 0.0000 \\
\hline
\end{tabular}

Sumber: Hasil olah data Eviews 7

Tabel 7 Reaksi dampak emas terhadap gangguan dari variabel lain

\begin{tabular}{|c|c|c|c|c|c|}
\hline \multicolumn{6}{|c|}{ Response of $\Delta$ GOLD: } \\
\hline Period & $\Delta \mathrm{JKII}$ & $\Delta \mathrm{GOLD}$ & $\triangle$ SILVER & $\triangle$ PLATINUM & $\triangle$ PALLADIUM \\
\hline 1 & 0.2176 & 10.1636 & 0.0000 & 0.0000 & 0.0000 \\
\hline 2 & 0.6879 & -0.1072 & 0.3697 & 0.2335 & -0.0058 \\
\hline 3 & 0.6097 & -0.1383 & -0.1197 & -0.0510 & -0.1652 \\
\hline 4 & -0.0740 & 0.0621 & 0.0322 & 0.0102 & 0.0180 \\
\hline 5 & -0.0532 & -0.0146 & 0.0244 & 0.0031 & 0.0279 \\
\hline 6 & 0.0135 & 0.0065 & -0.0109 & -0.0032 & -0.0049 \\
\hline 7 & 0.0033 & 0.0012 & -0.0009 & 0.0004 & -0.0027 \\
\hline 8 & -0.0013 & -0.0017 & 0.0014 & 0.0003 & 0.0007 \\
\hline 9 & -0.0002 & 0.0003 & -0.0002 & -0.0001 & 0.0002 \\
\hline 10 & 0.0001 & 0.0002 & -0.0001 & 0.0000 & -0.0001 \\
\hline
\end{tabular}

Sumber: Hasil olah data Eviews 7

Tabel 8 Reaksi dampak perak terhadap gangguan dari variabel lain

\begin{tabular}{|c|c|c|c|c|c|}
\hline \multicolumn{6}{|c|}{ Response of $\Delta$ SILVER: } \\
\hline Period & $\Delta \mathrm{JKII}$ & $\Delta$ GOLD & $\triangle$ SILVER & $\triangle$ PLATINUM & $\triangle$ PALADIUM \\
\hline 1 & 0.0206 & 0.1023 & 0.1912 & 0.0000 & 0.0000 \\
\hline 2 & 0.0180 & 0.0696 & -0.0410 & 0.0024 & 0.0033 \\
\hline 3 & 0.0138 & 0.0063 & -0.0030 & -0.0014 & -0.0047 \\
\hline 4 & 0.0011 & -0.007 & 0.0048 & 0.0009 & -0.0001 \\
\hline 5 & -0.0011 & 0.0012 & -0.0008 & -0.0002 & 0.0006 \\
\hline 6 & -0.0003 & 0.0005 & 0.0000 & 0.0000 & 0.0001 \\
\hline 7 & 0.0002 & -0.0002 & 0.0000 & 0.0000 & -0.0001 \\
\hline 8 & 0.0000 & 0.0000 & 0.0000 & 0.0000 & 0.0000 \\
\hline 9 & 0.0000 & 0.0000 & 0.0000 & 0.0000 & 0.0000 \\
\hline 10 & 0.0000 & 0.0000 & 0.0000 & 0.0000 & 0.0000 \\
\hline
\end{tabular}

Sumber: Hasil olah data Eviews 7

Tabel 9 Reaksi dampak platinum terhadap gangguan dari variabel lain

\begin{tabular}{crrrrr}
\hline Response of $\triangle$ PLATINUM: & \multicolumn{5}{c}{} \\
\hline Period & $\Delta$ JKII & $\Delta$ GOLD & $\Delta$ SILVER & $\Delta$ PLATINUM & $\Delta$ PALADIUM \\
\hline 1 & 1.6759 & 5.2456 & 3.9236 & 9.2531 & 0.0000 \\
2 & 0.6871 & 2.1659 & -0.6991 & -0.6733 & -0.4417 \\
3 & 0.7397 & 0.3932 & 0.5096 & -0.0478 & -0.4199 \\
4 & 0.0629 & 0.0731 & -0.0787 & 0.0458 & 0.0464 \\
5 & -0.0102 & 0.0217 & 0.0025 & -0.0092 & 0.0239 \\
6 & -0.0002 & -0.0151 & 0.0121 & 0.0011 & -0.0006 \\
7 & 0.0012 & 0.0037 & -0.0045 & -0.0004 & -0.0013 \\
8 & -0.0005 & 0.0006 & 0.0003 & 0.0001 & 0.0000 \\
9 & 0.0000 & -0.0006 & 0.0003 & 0.0001 & 0.0001 \\
10 & 0.0001 & 0.0002 & -0.0001 & 0.0000 & 0.0000 \\
\hline
\end{tabular}

Sumber: Hasil olah data Eviews 7

Uji ko-integrasi Johansen menunjukkan tidak satupun variable yang berkointegrasi dalam periode jangka panjang. Uji kausalitas Granger menunjukan bahwa emas dan paladium menunjukan hubungan kausalitas dua arah dengan indeks saham syariah, sedangkan untuk perak dan platinum hanya menunjukan hubungan kausalitas satu arah yang berarti setiap perubahan index saham syariah akan berpengaruh terhadap harga perak dan platinum. Hasil analisis impulse respons, dan Variance decomposition 
method menunjukkan effek dari setiap variable terhadap variable lainnya hanya terdapat pada periode 1 sampai dengan 5 dan menghilang pada periode selanjutnya atau hanya hubungan jangka pendek.

Hasil-hasil ini menunjukkan bahwa logam pasar saham syariah di Indonesia dapat secara efektif menggunakan emas, perak, platinum dan paladium sebagai alat lindung nilai (hedging tools).

Dan akhirnya hasil ini memberikan implikasi praktis bagi akademisi, praktisi yang bertindak sebagai

Tabel 10 Reaksi dampak paladinum terhadap gangguan dari variabel lain

\begin{tabular}{|c|c|c|c|c|c|}
\hline \multicolumn{6}{|c|}{ Response of $\triangle$ PALADIUM: } \\
\hline Period & $\Delta \mathrm{JKII}$ & $\Delta \mathrm{GOLD}$ & $\triangle$ SILVER & $\triangle$ PLATINUM & $\triangle$ PALADIUM \\
\hline 1 & 1.3047 & 3.6578 & 2.4538 & 4.7454 & 12.1049 \\
\hline 2 & 0.8410 & 0.4722 & -0.1610 & -0.6405 & 0.3797 \\
\hline 3 & 0.1821 & 0.0495 & 0.2346 & -0.0016 & -0.6932 \\
\hline 4 & -0.0847 & 0.0651 & -0.0612 & 0.0340 & -0.0022 \\
\hline 5 & 0.0118 & 0.0112 & 0.0008 & -0.0072 & 0.0246 \\
\hline 6 & 0.0112 & -0.0085 & 0.0044 & 0.0003 & -0.0015 \\
\hline 7 & -0.0015 & 0.0015 & -0.0013 & 0.0001 & -0.0004 \\
\hline 8 & -0.0012 & 0.0001 & 0.0005 & 0.0000 & 0.0003 \\
\hline 9 & 0.0002 & -0.0001 & -0.0001 & 0.0000 & 0.0000 \\
\hline 10 & 0.0001 & 0.0001 & -0.0001 & 0.0000 & -0.0001 \\
\hline
\end{tabular}

Sumber: Hasil olah data Eviews 7
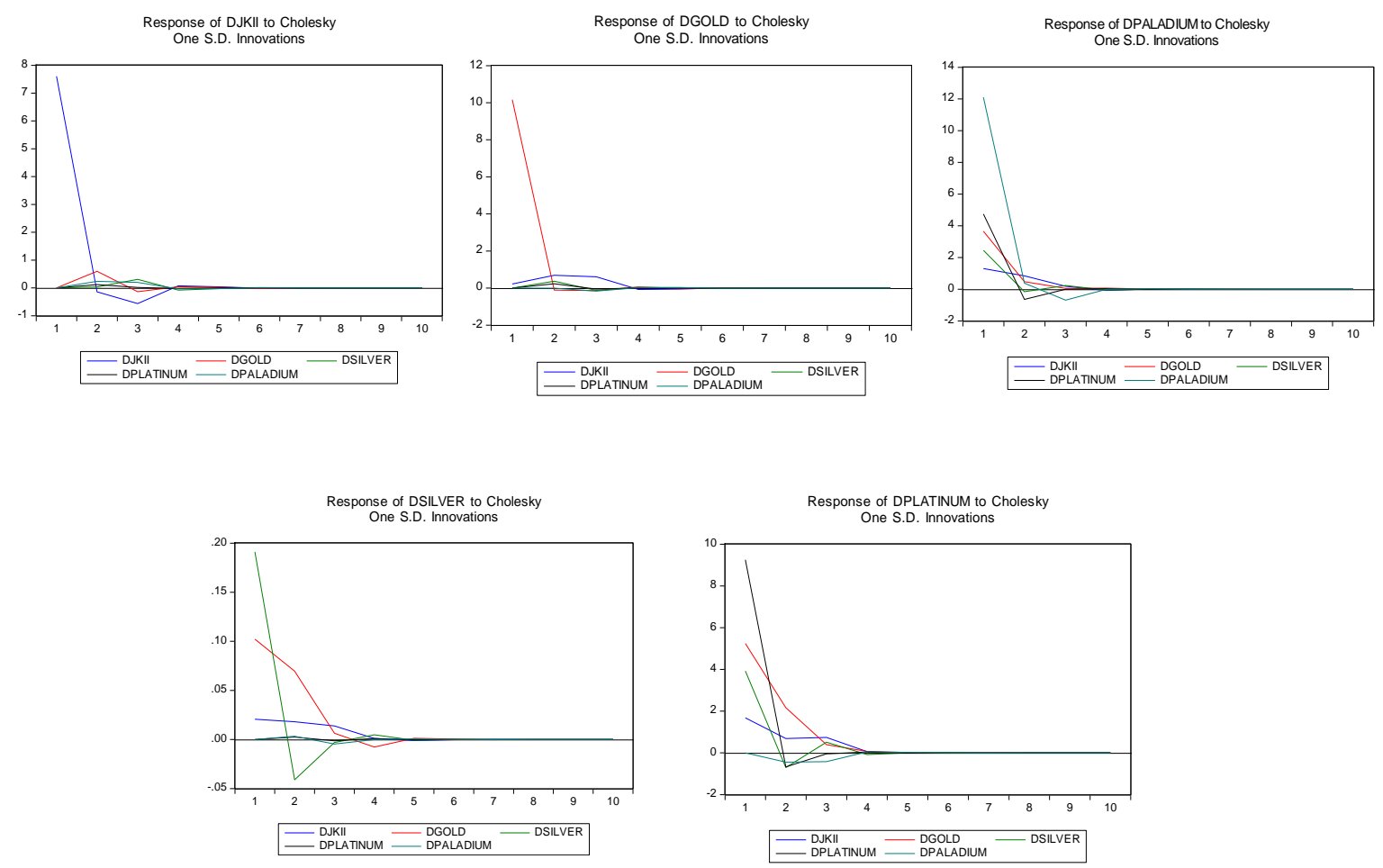

Sumber: Hasil olah data Eviews 7

Gambar 4 Impulse Response

mulia seperti emas, perak, platinum dan paladium adalah alat diversifikasi portofolio yang efektif untuk pasar saham syariah sesuai dengan penelitian dari (Abbes \& Trichilli, 2015; Arouri et al., 2015; Hood \& Malik, 2013; Nagayev et al., 2016). Dengan demikian, investor di pasar saham syariah di Indonesia mungkin menerima expected return dengan risiko minimum dengan menggunakan alat diversifikasi logam mulia (emas, perak, platinum dan paladium). Selanjutnya, studi ini penting bagi investor yang ingin membuat portofolio dengan memilih alat investasi yang sesuai dengan aturan Islam. Bagi pemerintah, investor individu, dan investor institusi yang berinvestasi di

portfolio manajer, dan pembuat kebijakan. Implikasi ini terkait dalam manajemen risiko portfolio, manfaat diversifikasi, dan untuk mengusulkan alat investasi baru yaitu pasar saham syariah di Indonesia. Dalam penelitian selanjutnya, penggunaan logam mulia dalam pasar saham syriah ini juga dapat diteliti menggunakan berbagai model pemilihan portofolio. Studi selanjutnya sangat penting dalam menentukan kegunaan logam mulia, penempatan dana investasi, dan pengaruh pemilihan portofolio. Dengan studistudi ini diharapkan dapat diperoleh hasil yang relatif lebih efektif. 


\section{REFERENSI}

Abbes, M. B., \& Trichilli, Y. (2015). Islamic stock markets and potential diversification benefits. Borsa Istanbul Review, 15(2), 93-105.

Abdul Karim, B., Akila Mohd. Kassim, N., \& Affendy Arip, M. (2010). The subprime crisis and Islamic stock markets integration. International Journal of Islamic and Middle Eastern Finance and Management, 3(4), 363371.

Ajmi, A. N., Hammoudeh, S., Nguyen, D. K., \& Sarafrazi, S. (2014). How strong are the causal relationships between Islamic stock markets and conventional financial systems? Evidence from linear and nonlinear tests. Journal of International Financial Markets, Institutions and Money, 28, 213-227.

Al-Khazali, O., Lean, H. H., \& Samet, A. (2014). Do Islamic stock indexes outperform conventional stock indexes? A stochastic dominance approach. Pacific-Basin Finance Journal, 28, 29-46.

Andersen, T. G., Bollerslev, T., Diebold, F. X., \& Labys, P. (2003). Modeling and forecasting realized volatility. Econometrica, 71(2), 579625.

Arouri, M. E. H., Lahiani, A., \& Nguyen, D. K. (2015). World gold prices and stock returns in China: insights for hedging and diversification strategies. Economic Modelling, 44, 273-282.

Ashraf, D., \& Mohammad, N. (2014). Matching perception with the reality-Performance of Islamic equity investments. Pacific-Basin Finance Journal, 28, 175-189.

Baur, D. G., \& Lucey, B. M. (2010). Is gold a hedge or a safe haven? An analysis of stocks, bonds and gold. Financial Review, 45(2), 217-229.

Chkili, W. (2017). Is gold a hedge or safe haven for Islamic stock market movements? A Markov switching approach. Journal of Multinational Financial Management, 42, 152-163.

Choudhry, T., Hassan, S. S., \& Shabi, S. (2015). Relationship between gold and stock markets during the global financial crisis: Evidence from nonlinear causality tests. International Review of Financial Analysis, 41, 247-256.

Dickey, D. A., \& Fuller, W. A. (1979). Distribution of the estimators for autoregressive time series with a unit root. Journal of the American statistical association, 74(366a), 427-431.

Engle, R. F., \& Granger, C. W. (1987). Co-integration and error correction: representation, estimation, and testing. Econometrica: journal of the Econometric Society, 251-276.
Gheeraert, L., \& Weill, L. (2015). Does Islamic banking development favor macroeconomic efficiency? Evidence on the Islamic financegrowth nexus. Economic Modelling, 47, 3239.

Hamao, Y., Masulis, R. W., \& Ng, V. (1990). Correlations in price changes and volatility across international stock markets. The review of financial studies, 3(2), 281-307.

Haseeb, M. (2018). Emerging issues in islamic banking \& finance: Challenges and Solutions. Academy of Accounting and Financial Studies Journal, 22, 1-5.

Hood, M., \& Malik, F. (2013). Is gold the best hedge and a safe haven under changing stock market volatility? Review of Financial Economics, 22(2), 47-52.

Johansen, S. (1988). Statistical analysis of cointegration vectors. Journal of economic dynamics and control, 12(2-3), 231-254.

Ling, S., \& McAleer, M. (2003). Asymptotic theory for a vector ARMA-GARCH model. Econometric theory, 19(2), 280-310.

Majid, A., \& Shabri, M. (2018). Who Co-Moves The Islamic Stock Market of Indonesia-The US, The UK, or Japan? Al-Iqtishad Journal of Islamic Economics, 10(2), 267-284.

Mensi, W., Hammoudeh, S., \& Kang, S. H. (2015). Precious metals, cereal, oil and stock market linkages and portfolio risk management: Evidence from Saudi Arabia. Economic Modelling, 51, 340-358.

Nagayev, R., Disli, M., Inghelbrecht, K., \& Ng, A. (2016). On the dynamic links between commodities and Islamic equity. Energy Economics, 58, 125-140.

Robiyanto, R. (2018). Testing of the Gold's Role as a Safe Haven and Hedge for Sharia Stocks in Indonesia. Al-Iqtishad Journal of Islamic Economics, 10(2), 255-266.

Sensoy, A. (2013). Dynamic relationship between precious metals. Resources Policy, 38(4), 504-511.

Suciningtias, S. A., \& Khoiroh, R. (2015). Analisis dampak variabel makro ekonomi terhadap indeks saham syariah indonesia (ISSI). Paper presented at the Conference In Business, Accounting, And Management (CBAM).

Tuna, G. (2019). Interaction between precious metals price and Islamic stock markets. International Journal of Islamic and Middle Eastern Finance and Management, 12(1), 96114. 